\title{
A national-scale assessment of climate change impacts on species: assessing the balance of risks and opportunities for multiple taxa
}

Article

Accepted Version

Creative Commons: Attribution-Noncommercial-No Derivative Works 4.0

Pearce-Higgins, J. W., Beale, C. M., Oliver, T. H., August, T. A., Carroll, M., Massimino, D., Ockendon, N., Savage, J., Wheatley, C. J., Ausden, M. A., Bradbury, R. B., Duffield, S. J., Macgregor, N. A., McClean, C. J., Morecroft, M. D., Thomas, C. D., Watts, O., Beckmann, B. C., Fox, R., Roy, H. E., Sutton, P. G., Walker, K. J. and Crick, H. Q. P. (2017) A national-scale assessment of climate change impacts on species: assessing the balance of risks and opportunities for multiple taxa. Biological Conservation, 213 (A). pp. 124-134. ISSN 00063207 doi: https://doi.org/10.1016/j.biocon.2017.06.035 Available at https://centaur.reading.ac.uk/71437/

It is advisable to refer to the publisher's version if you intend to cite from the work. See Guidance on citing.

To link to this article DOI: http://dx.doi.org/10.1016/j.biocon.2017.06.035

Publisher: Elsevier 
including copyright law. Copyright and IPR is retained by the creators or other copyright holders. Terms and conditions for use of this material are defined in the End User Agreement.

\section{www.reading.ac.uk/centaur}

\section{CentAUR}

Central Archive at the University of Reading

Reading's research outputs online 
A national-scale assessment of species distributions and climate change: implications of changing distributions for future conservation

James W. Pearce-Higgins ${ }^{1,2}$, Colin M. Beale ${ }^{3}$, Tom H. Oliver ${ }^{4,5}$, Tom A. August ${ }^{4}$, Matthew Carroll $^{3,6,7}$, Dario Massimino ${ }^{1}$, Nancy Ockendon ${ }^{1,2}$, Joanne Savage ${ }^{4}$, Christopher J.

Wheatley $^{3}$, Malcolm A. Ausden ${ }^{6}$, Richard B. Bradbury ${ }^{2,6,7}$, Simon J. Duffield ${ }^{8}$, Nicholas A. Macgregor ${ }^{8,9}$, Colin McClean $^{10}$, Michael D. Morecroft ${ }^{8}$, Chris D. Thomas $^{3}$, Olly Watts ${ }^{6}$, Becky C. Beckmann ${ }^{3,411}$, Richard Fox ${ }^{12}$, Helen E. Roy ${ }^{4}$, Peter G. Sutton ${ }^{11}$. Humphrey Q.P. Crick $^{8}$

${ }^{1}$ British Trust for Ornithology, The Nunnery, Thetford, Norfolk, IP24 2PU, UK

${ }^{2}$ Conservation Science Group, Department of Zoology, University of Cambridge, Downing Street, Cambridge CB2 3EJ, UK

${ }^{3}$ Department of Biology, University of York, Wentworth Way, York, YO10 5DD, UK

${ }^{4}$ Centre for Ecology \& Hydrology, Maclean Building, Benson Lane, Crowmarsh Gifford, Wallingford, Oxfordshire, OX10 8BB,UK

${ }^{5}$ School of Biological Sciences, University of Reading, Whiteknights, Reading, Berkshire RG6 6AS, UK.

${ }^{6}$ Royal Society for the Protection of Birds, The Lodge, Sandy, Beds., SG19 2DL, UK

${ }^{7}$ RSPB Centre for Conservation Science, The David Attenborough Building, Pembroke Street, Cambridge CB2 3QZ, UK

${ }^{8}$ Natural England, Eastbrook, Shaftesbury Road, Cambridge, CB2 8DR, UK 
${ }^{9}$ Durrell Institute of Conservation and Ecology (DICE), School of Anthropology and Conservation, University of Kent, Canterbury, Kent, CT2 7NR, UK

${ }^{10}$ Environment Department, University of York, Wentworth Way, York, YO10 5NG, UK

${ }^{11}$ Orthoptera and Allied Insects Recording Scheme of Britain and Ireland, clo Biological Records Centre, Centre for Ecology \& Hydrology, Wallingford, OX10 8BB, UK

${ }^{12}$ Butterfly Conservation, Manor Yard, East Lulworth, Wareham, Dorset, BH20 5QP, UK

Corresponding author: Pearce-Higgins, J.W. Email: james.pearce-higgins @bto.org, Tel: +44

(0)1842 750050

Word count $(9,266$ including references 2,144 , tables and figures 762$)$ 


\section{Abstract}

It is important for conservationists to be able to assess the risks that climate change poses to species, in order to inform decision making. Using standardised and repeatable methods, we present a national-scale assessment of the risks of range loss and opportunities for range expansion, that climate change could pose for over 3,000 plants and animals that occur in England. A basic risk assessment that compared projected future changes in potential range with recently observed changes classified $21 \%$ of species as being at high risk and $6 \%$ at medium risk of range loss under a B1 climate change scenario. A greater number of species were classified as having a medium (16\%) or high (38\%) opportunity to potentially expand their distribution. A more comprehensive assessment, incorporating additional ecological information, including potentially confounding and exacerbating factors, was applied to 402 species, of which $35 \%$ were at risk of range loss and $42 \%$ may expand their range extent. This study covers a temperate region with a significant proportion of species at their poleward range limit. The balance of risks and opportunities from climate change may be different elsewhere. The outcome of both risk assessments varied between taxonomic groups, with bryophytes and vascular plants containing the greatest proportion of species at risk from climate change. Upland habitats contained more species at risk than other habitats. Whilst the overall pattern was clear, confidence was generally low for individual assessments, with the exception of well-studied taxa such as birds. In response to climate change, nture conservation needs to plan for changing species distributions and increasing uncertainty of the future.

Keywords: adaptation, , Great Britain, risk assessment, vulnerability, climate envelope. 


\section{Introduction}

To make the best use of conservation resources, it is necessary to prioritise species, for example according to their current status and the threats that they face. Globally, the most widely adopted framework for this is the IUCN Red List which quantifies extinction risk using information on the population size and range extent of a species, and the rate of change in those parameters (Mace et al., 2008, IUCN 2016). Anthropogenic climate change is likely exacerbate the extinction risk of many species over the course of this century (Thomas et al., 2004, Bellard et al., 2012, Warren et al., 2013, Foden et al., 2013). A number of approaches have been developed to assess the potential impact of climate change on species' future status (Akçakaya et al., 2015). One common approach uses species distribution models (widely termed bioclimatic-envelope or climate-envelope models) to link distribution to climate variables and project the likely future impact of climate change on species' distributions (e.g. Thomas et al., 2004, Huntley et al., 2007, Walmsley et al., 2007, Warren et al., 2013). An alternative approach is to undertake vulnerability assessments which may combine a measure of future projected climate change (exposure) with ecological traits to identify the sorts of species most likely to both be sensitive to and lack the capacity to adapt to climate change (e.g. Gardali et al., 2012, Foden et al., 2013).

Vulnerability assessments have often been applied to single taxonomic groups within particular regions or countries (e.g. Heikkinen et al., 2010, Barbet-Massin et al., 2012) or, less commonly across a global scale (Jetz et al., 2007, Foden et al., 2013). Relatively few vulnerability assessments have covered the full range of biodiversity present within a particular geographical area, despite the fact that a comprehensive assessment of as many taxa as possible would assist governments and conservation organisations plan and adapt to climate change. Achieving such wide coverage is challenging because many assessments 
require taxon-specific information or approaches and have limited applicability to other taxa (e.g. Heikkinen et al., 2010, Gardali et al., 2012, Moyle et al., 2013) . To date, it has been difficult to develop an approach which works across a range of taxa due to the different nature of ecological traits across contrasting taxonomic groups, and the variable availability of data (e.g. of species distributions, trends and traits). The strong tradition of biological recording in Britain across a wide range of taxa provides a rare opportunity to tackle this challenge.

Thomas et al., (2010) developed a framework to assess the threats and potential benefits of climate change that is applicable to a wide range of taxa. It uses bioclimatic-envelope models, combined with information on recent trends and additional ecological information, to identify the likelihood of species' range expansion and contraction, and has so far been applied to UK butterflies and some exemplar species from other taxa (Thomas et al., 2010). Here, we use a modification of this approach to undertake a climate change vulnerability assessment of over 3,000 terrestrial and wetland species, species aggregates and distinctive subspecies or varieties (hereafter species; see methods) across 17 taxonomic groups in Britain. This provides the first opportunity to examine how an important aspect of vulnerability to climate change varies between taxonomic groups, and between species associated with specific habitat types, for as complete a biological assemblage as currently feasible.

This study was developed as part of a wider initiative of Natural England, the government conservation agency in England, to support decision making on adaptation (Natural England 2014) and inform an adaptation plan (Natural England, 2015). It focuses on species in England, the largest of the component countries within the United Kingdom (UK), but assesses the vulnerability of those species across Great Britain (GB), as this better represents the unit of contiguous land across which conservation decisions are made within the UK. 


\section{Materials and Methods}

The vulnerability assessment involved a number of steps (Figure 1) outlined below:

1. Distribution data for over 5,000 species (strictly mixed taxonomic concepts hereafter referred to as species) were collated for a wide range of taxa that occur in England (Table 1).

2. Statistical models linking species' distributions to climate were used to assess the likely impacts of future climate change upon species' potential distributions.

3. Information from these projections was compared with observed changes in species distribution. By assessing recently observed changes in the context of projected future trends, a simplified risk assessment could be undertaken rapidly across all species.

4. For a representative subset of 402 species, additional ecological information enabled the application of the full Thomas et al., (2010) framework. By considering the potential for non-climatic factors and ecological constraints to affect species' responses to climate change, this framework produces a more comprehensive assessment (the full risk assessment).

Whilst the term 'risk assessment' can have specific meanings in different contexts, we follow Thomas et al. (2010) and use it to describe our methodology for assessing the potential risks and opportunities that climate change may pose for species.

Species distribution data 
Species distribution data for GB were available from a range of biological recording schemes for a total of seventeen taxonomic groups (Table 1) at a hectad (10 km square) resolution. For inclusion species had to be present in England and recorded on more than 5 hectads (the minimum required for modelling; Hickling et al., 2006). Even with this threshold the climate envelope models (described below) failed to converge for the most sparsely distributed species (c. 10\%), giving a total of 4,540 species for which modelling was possible.

We used data from 1970-89 to represent baseline distributions prior to recent climate change, in order to minimise the risk of species' distributions being unsynchronised with the climate due to recent range shifts (Mason et al. 2015). For plants we used the period 1970-86; the time period (Braithwaise \& Walker 2012) that most closely matched the data for other taxa. For birds the period 1988-91 was used, which coincided with a national atlas (Gibbons et al., 1993). Cells for which climate data were not available were excluded from analyses. To aid model convergence small islands, with little data, were also excluded from analyses for all taxa apart from birds, leaving 2,561 hectads, or 2,670 for birds.

Recording effort varies between taxa, with the highest coverage for groups with welldeveloped and popular volunteer recording schemes such as vascular plants, birds and butterflies. To avoid species' distribution models being biased as a result of limited recording effort, we used the program FRESCALO (Hill, 2012) to estimate taxon-specific recorder effort in each $10 \mathrm{~km}$ square (see below).

\section{Species distribution modelling}

We used the climate envelope modelling approach of Beale et al., (2014) across all taxa (Appendix 1). The approach was devised to address the problem of spatial autocorrelation in large-scale species' distribution data, and applies a Bayesian, spatially explicit (Conditional Autoregressive) Generalised Additive Model to species' distribution data in order to separate 
climatic, spatial and random components in determining the distribution of each species. Four bioclimate variables were used to describe spatial variation in the climate, using 1961-1990 averages:

- mean temperature of the coldest month (MTCO): a measure of winter cold.

- growing degree days above $5^{\circ} \mathrm{C}$ (GDD5): a measure of biologically useful warmth, calculated by applying a spline to mean monthly temperatures for each cell to convert monthly data to daily estimates.

- the coefficient of variation of temperature (cvTemp): a measure of seasonality

- soil moisture (soilWater): a measure of moisture availability calculated following the bucket model of Prentice et al., (1992), which takes inputs of temperature, rainfall, \% sun/cloud and soil water capacities.

For birds and vascular plants, we initially constructed species $50 \mathrm{~km}$ resolution distribution models across Europe to describe the relationship between occurrence and climate using uninformative priors (i.e. with no prior knowledge of what this relationship should be). Once converged, a second model was fitted to hectad data from GB using informative priors from the European-scale analysis. As a result, any strong climatic signal based on the European distribution would remain essentially unchanged when modelled using GB data only, unless there was strong evidence for a different climatic signal within GB. In cases where there was high uncertainty in the estimation of species' responses at a European level, the GB model would be more heavily informed by outputs from the British component of the model. We tested for differences between both models for birds and vascular plants under the A1B scenario. Predicted changes were strongly correlated, although models based on GB only data tended to result in fewer species showing potential increases in range (Appendix 1). For 
species for which data from GB only were available, only the second model was run using uninformative priors.

As there was a strong correlation between the results of the A1B and the B1 scenario, we focus on the B1 results in this paper. These represent the species' potential vulnerabilities to the magnitude of climate change under a low emissions scenario projected to lead to a $c .2^{\circ} \mathrm{C}$ global temperature increase by the end of this century. Results from the A1B scenario are presented in Appendix 1, representing vulnerabilities under a medium emissions scenario of c. $4^{\circ} \mathrm{C}$ global warming by the end of this century.

\section{Simplified risk assessment}

Distribution data from national schemes were used to identify post-1989 range changes within the baseline historical distribution (1970-89; or 1970-86 for plants and 1988-91 for birds, as described above), and outside this historic range (newly colonised areas). With the exception of birds, distributional changes required the following correction to account for variation in observer effort (Hill 2012, Roy et al., 2012), as described in Appendix 2.

Due to limited data availability across adequately sampled squares, it was not possible to use this method to produce effort-corrected observed trends for 1,492 species, leaving a total of 3,048 to which the risk assessment could be applied. Of these, 50 were species aggregates reflecting taxonomic changes over previous decades ( 1 bird, 3 carabid beetles, 28 bryophyte and 18 vascular plants), 123 were specific subspecies or varieties ( 38 bryophyes, 2 spiders and 83 vascular plants), and 80 were infraspecies, whose distribution may have been based on partial information, due to the separate recording of taxonomically distinct subspecies or related species aggregates ( 31 bryophytes, 1 carabid beetle and 48 vascular plants). The inclusion of this mix of taxonomic resolutions did not bias the risk assessment towards species of particular risk or opportunity categories; there was no significant difference in the 
allocation to different risk categories between 'true' species and these other taxonomic concepts combined, under either the B1 $\left(\chi_{4}^{2}=7.93, P=0.094\right)$ or $\mathrm{A} 1 \mathrm{~B}\left(\chi_{4}^{2}=7.44, P=0.11\right)$ scenarios. We have therefore assessed all taxonomic concepts together, but for completeness also present the results for bryophytes and vascular plant species separately, excluding aggregates, subspecies and infraspecies.

Current contractions within the historical range were compared against the magnitude of projected future contractions to assess risk from climate change, whilst observed range expansion was cross-tabulated with the magnitude of projected future range expansion to assess potential threats and opportunities from climate change (Appendix 3). The highest threat or opportunity categories were reserved for those species where projected future changes were consistent with observed changes. As the simplified risk assessment may have inflated the potential risk of climate change for species which have suffered recent declines and range contractions for non-climatic reasons, for a subset of 402 species, we also undertook a full risk assessment following the Thomas et al., (2010) framework to account for non-climatic factors and constraints.

\section{Full risk assessment}

The 402 species (including 4 subspecies / varieties and 1 infraspecies) for full assessment comprised 155 conservation priority species listed under the Section 41 of the Natural Environment and Rural Communities (NERC) Act 2006 (http://www.legislation.gov.uk/ukpga/2006/16/pdfs/ukpga_20060016_en.pdf), termed NERC species, as well as at least 13 randomly selected species from each taxonomic group. This provided a broad appraisal across taxa, while ensuring as many species of highest conservation concern as possible were included. The full risk assessment provided a confidence level for each observed and projected population trend using additional ecological 
information linking population and range changes to climate, and on potential exacerbating factors (e.g. range extent and population size, ecological constraints associated with habitatavailability, dispersal and species interactions). This information was gathered from a literature search for each species using Google Scholar and Web of Science, supplemented by additional information from UK species experts (see Acknowledgements). The confidence associated with ecological information was regarded as good if based upon peer-reviewed literature. If it was based on expert knowledge then the expert was asked to assign the confidence level.

The full risk assessment consisted of four stages (Figure 2, Apppendix 4), requiring information on observed changes in occurrence within the current range (Stage I), projected changes within the current range (Stage II), observed changes in occurrence outside the current range (Stage III) and projected changes outside the current range (Stage IV). The results of the four stages were synthesised into a single table (Table A4). The overall confidence for species 'at risk' was the confidence associated with the assessment of threat, while for species likely to benefit we used the confidence associated with the likely opportunity. For species classed as having 'risks and opportunities' or 'limited impact', we averaged the two confidence scores.

\section{Statistical analysis}

Significant differences in the proportion of species allotted to different risk categories were tested by Chi-square, as were contrasts between taxonomic groups and between NERC and other species. Information on the broad ahabitat associations of the 155 NERC priority species, summarised into wetland, urban, farmland, upland woodland and coastal categories was used to test the extent to which species' vulnerability to climate change, from the full risk assessment, varied between habitats. 
Formal differences between the results from the simplified and full risk assessments for each of the 402 species assessed using both risk assessment methods, were tested by Chi-square test and by regression. For the latter, we converted the categorical risk assessment into rank scores from high risk (-2) to high opportunity (2), with both 'risks \& opportunities' and 'limited impact' categories scored as 0 . Scores were regressed within a generalised linear mixed model, with taxonomic identity as a random effect, using PROC MIXED in SAS v9.2. We used the same scores to test for differences in full risk assessment outcomes between different taxa, and between NERC and other species.

\section{Results}

\section{Simplified risk assessment}

Of the 3,048 species assessed, 640 were classified as being at high risk of a decline in the area of projected suitable climate under the B1 climate change scenario and 188 at medium risk (a total of $27.2 \%$ species at risk). A greater number of species were identified as likely to have a medium $(486)$ or high $(1,164)$ potential opportunity as a result of projected increases in the area of potentially suitable climate (totalling 54.1\%; Table 2). For only 6 was limited impact predicted. These estimates of risk were similar under the A1B warming scenario ( $\left.\chi_{5}^{2}=2.96, P=0.71\right)$, although with slightly more species (28.1\%) classified as being at risk (Appendix 1).

The outcome of the risk assessment varied significantly between taxonomic groups $\left(\chi_{64}^{2}=\right.$ 475.54, $P<0.0001$; excluding the limited impact category due to the small sample size). These differences remained $\left(\chi_{32}^{2}=339.73, P<0.0001\right)$ when simply splitting species into those at risk, likely to have an opportunity, or likely to be unaffected (i.e. risks \& opportunities and limited impact categories combined). The proportion of species at risk 
varied from $6 \%$ for wasps to $39 \%$ for vascular plants, while the proportion of species with opportunity varied from $37 \%$ for bryophytes to $90 \%$ for wasps (Figure 3). Repeating this appraisal for bryophytes and vascular plants without subspecies and infraspecies produced equivalent assessments for both (bryophytes: high benefit 107 spp (25\%), medium benefit 48 spp. (11\%), risks and benefits 134 spp. (32\%), medium risk 32 spp. (8\%), high risk 102 spp. (24\%); vascular plants: high benefit 210 spp. (30\%), medium benefit 103 spp. (15\%), risks and benefits 131 spp. (19\%), medium risk 59 spp. (8\%), high risk 200 spp (28\%)). The groups with the greatest proportion of species at risk from climate change were bryophytes and vascular plants (> $30 \%$ in both cases), whilst a number of groups were largely (>70 \%) comprised of species for which climate change may present an opportunity for range expansion in GB (ants, bees, centipedes, coccinellid beetles and wasps).

NERC species contained slightly more 'high risk' and 'medium opportunity' species and fewer 'high opportunity' species than expected from the pattern across the other species ( $\left.\chi_{4}^{2}=10.30, P=0.036\right)$, but there was no overall difference between these two species groups when the categories were simplified to risk, opportunity or unaffected $\left(\chi_{2}^{2}=1.07, P=0.58\right)$.

\section{Full risk assessment}

Across all 402 species run through the full framework for the B1 scenario, 141 (35.1\%) were classified as being at high or medium risk of being negatively affected by climate change, compared to $168(41.8 \%)$ which were listed as likely to have a medium or high opportunity (Table 3). Limited impact was predicted for $19 \%$ of species. The score attributed to species did not vary between NERC species and the remainder $\left(\mathrm{F}_{1,384}<0.01, P=0.99\right)$, but did vary with taxonomic group $\left(\mathrm{F}_{16,384}=3.38, P<0.0001\right)$. The lowest scores, indicating the greatest proportion of species at risk from climate change, were for bryophytes $(n=14)$, with the 
highest scores for ants $(n=13)$ and wasps $(n=13)$, the majority of which were classed as having a high opportunity from climate change (Figure 4).

There was no significant variation overall between habitats in the frequencies of NERC species allocated to different risk categories $\left(\chi_{25}^{2}=33.86, P=0.11\right)$. However, upland was the only habitat with a majority of species $(75 \%)$ regarded as being at risk of a decline in the area of projected suitable climate (Figure 5), which contrasted significantly with average of $40 \%$ of species across the remaining habitats when lumped together $\left(\chi_{5}^{2}=15.59, P=0.008\right)$.

For the majority (314) of species in the full assessment, confidence was poor, for 86 it was medium and good for only two. Confidence scores differed significantly between taxonomic groups $\left(\chi_{16}^{2}=57.23, P<0.0001\right)$, driven primarily by a greater level of confidence for bird assessments (35\% of 82 assessments were accorded medium or good confidence) than for other species, where $18 \%$ of 320 assessments were classed as having medium confidence, and none good.

Simplified v Full Risk Assessment

There was a strong association between the scores using the simplified and full approaches for species assessed by both $\left(\mathrm{F}_{1,398}=955.56, P<0.0001 ; \mathrm{S}_{\mathrm{F}}=-0.33( \pm 0.089)+0.91( \pm\right.$ 0.029) $\mathrm{S}_{\mathrm{S}}$, where $\mathrm{S}_{\mathrm{F}}$ is the full assessment score and $\mathrm{S}_{\mathrm{S}}$ the simplified assessment score). The scores from the two frameworks had a close to 1:1 relationship, but the intercept shows that the full assessment on average produced a lower score by 0.33 (or one third of a category), a significantly higher threat or lower opportunity category.

\section{Discussion}


Here we present a national-level assessment of species' vulnerability to climate change, covering 3,048 species across 17 taxonomic groups. Consistently for both B1 and A1B scenarios, we found that there was a greater number of species for which potential range is projected to increase as a result of climate change than it is projected to decrease. This was particularly the case when considering the outputs for the simplified framework for all species, where over $50 \%$ were classified with a medium or high opportunity from climate change (Table 2), but also applied to $43 \%$ of the subset of species run through the full risk assessment framework, compared with projected negative range impacts for $35 \%$ (Table 3 ). This also concurs with the previously published results of the full risk assessment methodology for butterflies in GB, which used an A2 climate change scenario intermediate between the B1 and A1B scenarios used here (Thomas et al., 2010). Of 58 butterfly species, three were regarded as at high risk from climate change, three at medium risk, 10 likely to have a medium opportunity, 14 a high opportunity and 27 limited impact. If turned into rank scores and added to the results of our study, this would place butterflies intermediate between coccinelid beetles and craneflies, with a mean score of 0.52 (Figure 4). Our findings are also consistent with recently observed trends across multiple taxa in the UK where more species have been impacted positively by climate change than negatively, at least in the short-term (Burns et al., 2016).

It could be argued that by indicating that a greater number of taxa are likely to have an opportunity for range expansion in response to climate change than be at risk of range contraction, our analysis suggests that climate change will have a positive impact upon UK biodiversity. However, before considering this, it is worth noting how our findings may result from both underlying methodological constraints and inherent biological processes. 
It was not possible to undertake assessments for $13 \%$ of species because there were insufficient data to generate a bioclimate model, and for a further $29 \%$ of remaining species there was insufficient information to produce effort-corrected observed trends. Given latitudinal gradients in observer (recorder) effort within the UK, with more recorders in the south than the north, it is likely that a greater proportion of unassessed species were northerly-distributed and may include species more likely to be at risk of adverse climate change impacts than to benefit. By selecting species from England, but using data from across GB for their assessment, enabled us to include more northern and upland species than we otherwise would have done had we undertaken the assessment with distribution data from England alone. In addition, it is possible that the exclusion of data-deficient species excluded particularly the more localised and specialised species, which may be species less likely to benefit from climate change (e.g. Warren et al. 2001). We did observe a significant difference between the scores of conservation priority species (many of which are rare and specialised) and others in the simplified assessment, but there was no such difference in the full assessment.

Apart from birds and vascular plants, the biodiversity data underpinning the assessment were from GB only, and in most cases our models do not capture the full range of climaticallysuitable conditions in which the species can occur. A test of this for birds and vascular plants, which compared models based on GB data vs. GB + European data, suggested that GB-only projections tended to be slightly more pessimistic than those that included European data, although the two were strongly correlated. Thus, the use of GB-only projections for most groups may have slightly inflated the projected magnitude of risk for those groups, although the assessment for vascular plants, one of the groups with the greatest proportion of species 
regarded as being at risk from climate change, included European data in the assessment for over a quarter of species.

We assumed that the species distribution models describe the main relationships between species' occurrence and terrestrial climate. As we employed widely-used bioclimatic variables, this is probably reasonable for most terrestrial taxa, but for some coastal bird species which use the marine environment, where spatial patterns of changes in sea temperature and other climate related variables may differ from those on land, projections are likely to be less certain. We also have not considered potentially detrimental impacts of sealevel rise and storm surges upon vulnerable coastal habitats and species (e.g. Gilbert et al., 2010; Ausden 2014).

The full assessment that considered ecological factors known to influence observed changes in populations or distributions, or likely constraints on the impacts of climate change, was applied to 402 species only. By excluding these considerations, the simple assessment applied across all species may have over-attributed observed changes to potential impacts of climate change if they were consistent with future projections (such as for farmland birds, crickets or centipedes and millipedes; Eglington \& Pearce-Higgins 2012; Beckmann et al. 2015; Lee 2015; Burns et al., 2.), or under-estimated the potential magnitude of future climate change impacts if observed changes were opposite to future projections as a result of non-climatic factors. Although both methodologies delivered broadly comparable results, the full assessment did increase the proportion of species projected to experience only a limited impact of climate change, and included a greater proportion of species projected to be at risk from climate change.

Finally, there is considerable uncertainty about the likely pace of any distributional shift in response to climate change. Both bird and butterfly communities appear to be lagging behind 
the rate of warming observed across Europe (Devictor et al., 2012, Massimino et al., 2015); non-mobile groups, such as many of the vascular plants, may well lag even more. The ability of a species to disperse will be an important constraint on the extent to which some species can occupy any new areas of potential range in the future (Barbet-Massin et al., 2012), as will the availability of areas of potentially suitable habitat for colonisation (Thomas et al., 2012; Hiley et al., 2013), and underlying population dynamics (Mair et al. 2014). Although considerable uncertainty remains about the pace of these responses to climate change, these uncertainties were at least partially captured by the full risk assessment, which reduces the likelihood of opportunity as a result of climate change in species with constrained dispersal ability.

Despite the potential methodological constraints, there are good biological reasons to expect more species to be able to expand their range than are at risk of it contracting in response to climate in GB. This is because there are more southern species with potential for northward range expansion in Britain than there are northern species with southern range margins at risk of contraction (e.g. butterflies: Asher et al., 2001; vascular plants: Preston et al., 2002; birds: Balmer et al., 2013), leading to strong latitudinal gradients in species' richness (e.g. Eglington et al., 2015). In combination with largely polewards shifts that are projected to occur in the distribution of a range of taxa, and are already being observed (Mason et al., 2015), this would lead to more species being likely to expand their distributions in GB, than to contract. Observations of recent trends suggest that this is already the case (Massimino et al., 2015, Burns et al., 2016). Although we assessed that fewer species would be at risk of range contraction from climate change than have an opportunity, species of certain taxonomic groups and habitats were identified as being more vulnerable than others. In particular, the full risk assessments completed for those species of conservation concern for which the required data is available suggested that species associated with upland habitat-types, where 
increasing temperatures might be expected to result in northwards and upwards range contraction, would be particularly vulnerable to climate change. This is consistent with the results of other studies suggesting that northern or upland birds (Green et al., 2008, PearceHiggins 2010), butterflies (Thomas et al., 2010) and plants (Hill \& Preson 2015) may be more vulnerable to climate change than southern species. Multi-taxa assessments have found similar patterns (Walmsley et al., 2007; Araujo et al 2011), and there is already evidence of such impacts being observed (Morecroft \& Speakman 2015). While many taxonomic groups contain some species likely to be at risk from climate change and others with the potential to expand their distribution, the balance between these two outcomes will vary with the geographical and habitat bias of that group, as well as the ecological characteristics of the species, such as voltinism, diapause strategy, migratory strategy and growth rate (Bale et al., 2002). Other climate-influenced ecological changes will also affect species abundance and distribution in future through altered species interactions (Ockendon et al., 2014).

Geographical differences may partly account for the apparent high sensitivity to future climate change of bryophytes (Figures 3 and 4), many of which have a northern or northwestern distribution, associated with cool and damp conditions. Our analysis suggests that of all the taxonomic groups considered, they are likely to be one of the most at risk from a reduction in areas of suitable climate, conclusions broadly supported by Ellis (2015), who anticpted detrimental impacts of climate change on northern and upland bryophytes, although potential imacts on species associated with oceanic climates were more uncertain. . Even though there is some evidence for recent warming being associated with distribution shifts in some bryophytes (Bates \& Preston 2011), there are difficulties in disentangling these changes from decreases in acid and nitrogen deposition from the atmosphere (Roth et al., 2013). The basic assessment also identified vascular plants as containing a high proportion of species at risk from climate change. However climate change may provide more of an opportunity for 
range expansion in a greater proportion of vascular plants than bryophytes; the full risk assessment suggested 17/51 plants but only 1/14 bryophytes have an opportunity for range expansion from climate change (Figure 4), although it is worth noting that bryophytes probably have greater capacity for colonisation than vascular plants due to their spore-driven dispersal. Conversely the majority of Hymenoptera, particularly ants and wasps, have a southern distribution and were ranked as most likely to experience a high opportunity from climate change. This matches previous studies suggesting that populations of many Hymenoptera increase with warmer temperatures (Pearce-Higgins 2010, Burns et al., 2016), probably because they are thermophilc species largely constrained by temperature.

It is noteworthy that the majority of vulnerability of individual species using the full assessment (78\%) had poor confidence. If this is the case in Britain, which is one of the best studied and data rich parts of the world, climate change risk assessments in other parts of the world are likely to be even more uncertain. This emphasises the need for long-term monitoring and research to document and understand the impacts of climate change on biodiversity, particularly outside well-studied parts of Europe and North America (Ockendon et al., 2014). As a result, nature conservation organisations will have to integrate uncertainty and flexibility into their response to climate change. The taxa whose assessments were most robust were butterflies, where $46 \%$ of species assessments had medium or good confidence (Thomas et al., 2010), and birds, for which $35 \%$ of assessments were associated with medium or good confidence. These are the two best studied taxonomic groups in Britain with respect to the impacts of climate change on their populations (e.g. Devictor et al., 2012, Morecorft \& Speakman 2015), and therefore the groups where observed changes can be more confidently attributed to climate change, where appropriate. They are also much better monitored than the other groups, with robust distribution change and annual population estimates adding to the confidence of the risk assessment. 
The main tool underpinning this assessment was climate envelope modelling. Although the results of some basic models have been criticised in the literature (see Beale et al., 2008), there is increasing evidence linking climate envelope model predictions to observed bird population changes (Stephens et al., 2016) and we used newly developed modelling techniques designed to overcome many of these problems. The generality of the conclusions from such models are likely to be broadly realistic at the high-level taxonomic group or habitat level, even if associated with a high degree of uncertainty for individual species. The simplified risk assessment makes use of both observed and projected population and range changes to assess risks and opportunities, allowing assessments to be moderated by the extent to which observed and projected trends are in accordance. The full risk assessment additionally makes use of this ecological information on links between population or range changes and climate and on potential exacerbating factors to assess the degree of confidence in the assessment. This combination of climate envelope modelling with ecological information to assess the degree of constraint which species are likely to face in responding to climate change, and comparison with observed trends, is a step forward from the basic climate envelope modelling approach, whilst taking account of some of the potential constraints on a species-by-species basis (Thomas et al., 2011).

\section{Implications for nature conservation}

This analysis provides as near comprehensive an overview of how species ranges may change within a country under climate change as is currently possible. It goes beyond general principles of anticipating species range shift and provides an evidence-based assessment of the extent of change that is likely. The risk assessment indicates that, at a national level, the distributions of most species are liable to change. In the basic risk assessment only 6 out 3048 
species were identified as having both low risk and low opportunity, whilst the full assessment classified only 75 of 402 species as having both low opportunity and low risk. This is an important finding for nature conservation planning, suggesting that changing distributions are likely to become the norm, not the exception, in the coming years.

Whilst there are many species that could potentially benefit from an expanding area of potentially suitable climate, these opportunities will not be realised if individuals are not able to disperse. Dispersal may be limited by several factors including fragmentation, unsuitable habitats or low populations sizes and other pressures affecting healthy populations. Facilitating species movement is therefore likely to be a major challenge for future species conservation. Although , many taxa have shown evidence of poleward shifts in their distribution in Britain (Mason et al. 2015), this has been partly facilitated by a network of protected sites (Thomas et al. 2012), whose continued conservation and expansion becomes even more important in a changing climate.

The study also provides a greater clarity on the extent of threat to some species, particularly highlighting the vulnerability of upland taxa where many species are adapted to cool, wet conditions. For those species at risk of losing areas of potentially suitable climate, conservation actions to increase resilience (Morecroft et al., 2012), including the protection of key sites (Gillingham et al. 2015) and refugia (Suggitt et al., 2014), the maintenance of large or functional connected areas of semi-natural habitats within landscapes (Newson et al., 2014, Oliver et al., 2015, 2017) and direct management to promote in-situ persistence (Greenwood et al., 2015) will be important. An example of the latter is the potential to alter the management of vulnerable peatland habitats by raising water levels, likely to benefit plants, invertebrates and birds (Carroll et al., 2011, Bellamy et al. 2012). Reducing other non- 
climatic pressures on upland species may also increase the ability of their populations to cope with climate change (Pearce-Higgins \& Green 2014).

The confidence assessments emphasise that individual species assessments should be treated cautiously and that conservationists need to draw upon the full range of information available before decisions are made about climate change adaptation and conservation management. Nevertheless for many species this assessment provides the main indication of potential climate change risks and opportunities and accordingly, it can also highlight where further investigation and monitoring is necessary. It also emphasises the importance of planning to accommodate greater uncertainty about where species will survive and thrive in future. For site managers, this includes being aware of where their site is located in the context of the overall distribution of priority species (most simply, core, leading or trailing edges) and being prepared to adjust management priorities as situations change. To achieve this aim, the nature conservation organisations involved in this study are working to integrate these and comparable findings into their conservation practice, and to make this larger, emerging evidence base more accessible to conservation practitioners.

\section{Acknowledgements}

We would like to thank the many recorders who have contributed data and the national recording schemes and societies (listed in Table 1) that co-ordinate and collate data. In addition to the scheme organisers listed as authors, specific thanks go to Chris Preston and

Oli Pescott (British Bryological Society), Mark Telfer (Grund Beetle Recording Scheme), Tony Barber (British Myriapod \& Isopod Group (Centipede Recording Scheme)), John Kramer and Alan Stubbs (Cranefly Recording Scheme), Stuart Ball, Roger Morris, Joan Childs and Ellie Rotheray (Hoverfly Recording Scheme), Keith Alexander (Soldier Beetles, 
Jewel Beetles and Glow-worms Recording Scheme), Peter Harvey (Spider Recording Scheme). Such a project would not be possible without their contributions. We are grateful to JNCC and Defra for their support to the Biological Records Centre, and particularly to species experts who contributed their knowledge to parameterise and give feedback on the climate change risk decision framework: Mike Edwards, Dave Hubble, Paul Lee, Roger Morris and Mark Parsons. This project was funded by Natural England.

\section{References}

Akçakaya, H. R., Butchart, S. H. M., Watson, J. E. M. \& Pearson, R. G. 2015. Preventing species extinctions resulting from climate change. Nat. Clim. Ch. 4, 1048-1049.

Araújo, M.B., Alagador, D., Cabeza, M., Nogués-Bravo, D. \& Thuiller, W. 2011. Climate change threatens European conservation areas. Ecol. Lett. 14, 484-492.

Asher, J., Warren, E., Fox, R., Harding, P., Jeffcoat, G. \& Jeffcoate, S. 2001. Millennium Atlas of Butterflies in Britian and Ireland. OUP, Oxford.

Ausden, M. 2014. Climate change adaptation: putting principles into practice. Env. Manag. $54,685-698$.

Bale, J.S., Masters, G.J., Hodkinson, I.D., Awmack, C., Bezemer, M., Brown, V.K., Butterfield, J., Buse, A., Coulson, J.C., Farrar, J., Good, J.E.G., Harrington, R., Hartley, S., Hefin Jones, T., Lindroth, R.L., Press, M.C., Symrnioudis, I., Watt, A.D. \& Whittaker, J.B. 2002. Herbivory in global climate research: direct effects of rising temperature on insect herbivores. Glob. Ch. Biol. 8, 1-16. 
Balmer, D.E., Gillings, S., Caffrey, B.J., Swann, R.L., Downie, I.S. \& Fuller, R.J. 2013. Bird Atlas 2007-11: the breeding and wintering birds of Britain and Ireland. BTO Books, Thetford.

Barbet-Massin, M., Thuiller, W. \& Jiguet, F. 2012. The fate of European breeding birds under climate, land-use and dispersal scenarios. Glob. Ch. Biol. 18, 881-890.

Bates, J.W. \& Preston, C.D. 2011. Can the effects of climate change on British bryophytes be distinguished from those resulting from other environmental changes? In: eds. Zoltan Tuba, Nancy G. Slack \& Lloyd R. Stark. Bryophyte ecology and climate change. Cambridge University Press, New York. Pp 371-407.

Beale, C.M., Brewer, M.J. \& Lennon, J.J. 2014. A new statistical framework for the quantification of covariate associations with species distributions. Meth. Ecol. Evol. 5, 421432.

Beckmann, B.C., Purse, B.V., Roy, D.B., Roy, H.E., Sutton, P.G., Thomas, C.D. 2015. Two species with an unusual combination of traits dominate responses of British grasshoppers and crickets to environmental change, PLoS ONE 10, e0130488

Bellamy, P.E., Stephen, L., Maclean, I.S. \& Grant, M.C. 2012. Response of blanket bog vegetation to drain blocking. Appl. Veg. Sci. 15: 129-135.

Bellard, C., Bertelsmeier, C., Leadley, P., Thuiller, W. \& Courchamp, F. 2012. Impacts of climate change on the future of biodiversity. Ecol. Lett. 15, 365-377.

Braithwaite, M.E. \& Walker, K.J. 2012. 50 Years of Mapping the British and Irish Flora 1962-2012. Botanical Society of the British Isles, London. 
Burns, F., Eaton, M.A., Barlow, K.E., Beckmann,B.C., Brereton, T., Brooks, D.R., Brown, P.M.J., Fulaij, N.A., Gent, T., Henderson, I., Noble, D.G., Parsons, M., Powney, G.D., Roy, H.E., Stroh, P., Walker, K., Wilkinson, J.W., Wotton, S.R. \& Gregory, R.D. 2016. Agricultural Management and Climatic Change Are the Major Drivers of Biodiversity Change in the UK. PLoS ONE 11, e0151595.

Carroll M.J., Dennis P., Pearce-Higgins J.W. \& Thomas C.D. 2011. Maintaining northern peatland ecosystems in a changing climate: effects of soil moisture, drainage and drain blocking on craneflies. Glob. Ch. Biol. 17, 2991-3001.

Devictor, V., van Swaay, C., Brereteon, T., Brotons, L., Chamberlain, D., Heliölä, J., Herrando, S., Julliard, R., Kuussaari, M., Linström, Å., Reif, J., Roy, D.B., Schweiger, O., Settele, J., Stefanescu, C., Van Strien, A., Van Turnhout, C., Vermouzek, Z., De Vries, M.W., Wynhoff, I. \& Jiguet, F. 2012. Differences in the climate debts of birds and butterflies at a continental scale. Nat. Clim. Ch. 2, 121-124

Eglington, S.M., Brereton, T.M., Tayleur, C.M., Noble, D., Risely, K., Roy, D.B. \& PearceHiggins, J.W. 2015. Patterns and causes of covariation in bird and butterfly community structure. Land. Ecol. 30, 1461-1472

Eglington, S.M \& Pearce-Higgins, J.W. 2012. Disentangling the relative importance of change in climate and land-use intensity in driving recent bird population trends. PLoS ONE 7, e30407.

Ellis, C. 2015. Implications of climate change for UK bryophytes and lichens. Technical biodiversity climate change impacts report card technical paper, 8 .

Foden, W.B., Butchart, S.H.B., Stuart, S.N., Vié, J.-C., Akçakaya, H.R., Angulo, A., DeVantier, L.M., Gutsche, A., Turak, E., Cao, L., Donner, S.D., Katariya, V., Bernard, R., 
Holland, R.A., Hughes, A.F., O’Hanlon, S.E., Garnett, S.T., Şekercioğlu. Ç. H., Mace, G.M. 2013. Identifying the World's Most Climate Change Vulnerble Species: A Systematic TraitBased Assessment of all Birds, Amphibians and Corals. PLoS ONE 8, e65427.

Gardali, T., Seavy, N.E., DiGaudio, R.T. \& Comrack, L.A. 2012. A climate change vulnerability assessment of California’s at-risk birds. PLoS ONE 7, e29507.

Gibbons, D.W., Reid, J.B. \& Chapman, R.A. 1993. The New Atlas of Breeding Birds in Britain and Ireland: 1988-1991. London, UK: Poyser.

Gilbert, G., Brown, A.F. \& Wotton, S.R. 2010. Current dynamics and predicted vulnerability to sea-level rise of a threatened Bittern Botaurus stellaris population. Ibis 152, 580-589.

Green, R.E., Collingham, Y,C. Willis, S.G., Gregory, R.D. \& Smith, K.W. 2008, Performance of climate envelope models in retrodicting recent changes in bird population size from observed climatic change. Biol. Lett. 4, 599-602.

Greenwood, O., Mossman, H.L., Suggitt, A.J., Curtis, R.J. \& Maclean, I.D. 2016. Using in situ management to conserve biodiversity under climate change. J. Appl. Ecol. 53, 885-894.

Hagemeijer, W.J.M. \& Blair, M.J. 1997. The EBCC Atlas of European Breeding Birds. T\&AD POYSER.

Heikkinen, R. K., Luoto, M., Leikola, N., Pöyry, J., Settele, J., Kudrna, O., Marmion, M., Fronzek, S. \& Thuiller, W. 2010. Assessing the vulnerability of European butterflies to climate change using multiple criteria. Biod. \& Conserv. 19, 695-723,

Hickling, R., Roy, D.B., Hill, J.K., Fox, R. \& Thomas, C.D. 2006. The distributions of a wide range of taxonomic groups are expanding polewards. Glob. Ch. Biol. 12, 450-455. 
Hill, M. O. 2012. Local frequency as a key to interpreting species occurrence data when recording effort is not known. Meth. Ecol. Evol. 3, 195-205.

Hill, M. O. \& Preston C. D. 2015. Disappearance of boreal plants in southern Britain: habitat loss or climate change? Biol. J. Linn. Soc. 115, 598-610.

Hiley, J.R., Bradbury, R.B., Holling, M. \& Thomas, C.D. 2013. Protected Areas act as establishment centres for species colonising the United Kingdom. Proc. Roy. Soc. B Biol. Sci. 280, 1-8.

Huntley, B., Green, R.E., Collingham, Y.C. \& Willis, S.G. 2007 A climatic atlas of European breeding birds. Lynx Edicions.

IUCN 2016. The IUCN Red List of Threatened Species. Version 2016-1. www.iucnredlist.org.

Jetz, W., Wilcove, D.S. \& Dobson, A.P. 2007. Projected impacts of climate and land-use change on the global diversity of birds. PLoS Biology 5, e157.

Lee, P. 2015. A review of the millipedes (Diplopoda), centipedes (Chilopoda) and woodlice (Isopoda) of Great Britain. Species Status No.23, Natural England Commissioned Reports, 1170, http://publications.naturalengland.org.uk/publication/4924476719366144

Mace, G. M., Collar, N. J., Gaston, K. J., Hilton-Taylor, C., Akçakaya, H.R., LeaderWilliams, N., Milner-Gulland, E.J. \& Stuart, S.N. 2008. Quantification of extinction risk: IUCN's system for classifying threatened species. Conserv. Biol. 22, 1424-1442.

Mair, L., Hill, J.K., Fox, R., Botham, M., Brereton, T. \& Thomas, C.D. 2014. Abundance change and habitat availability drive speces' responses to climate change. Nat. Clim. Ch. $4,127-131$ 
Mason, S.C, Palmer, G., Fox, R., Gillings, S., Hill, J.K., Thomas, C.D. \& Oliver, T.H. 2015. Geographical range margins of many taxonomic groups continue to shift polewards. Biol. J. Linn. Soc. 115, 586-597

Massimino, D., Johnston, A. \& Pearce-Higgins, J.W. 2015. The geographical range of British birds expands during 15 years of warming. Bird Study 62, 523-534

Mitchell, T.D., Carter, T.R., Jones, P.D., Hulme, M. \& New, M. 2004. A comprehensive set of high-resolution grids of monthly climate for Europe and the globe: the observed record (1901-2000) and 16 scenarios (2001-2100). Tyndall Centre Working Paper 55. Pp30.

Morecroft, M.D., Crick, H.Q.P., Duffield, S.J., Macgregor, N.A. 2012. Resilience to climate change: translating principles into practice. J. Appl. Ecol. 49, 547-551.

Morecroft, M. and Speakman, L (eds.) 2015.Terrestrial Biodiversity Climate Change Impacts Summary Report. Living With Environmental Change. http://www.nerc.ac.uk/research/partnerships/lwec/products/report-cards/biodiversity/ Moyle, P. B., Kiernan, J. D., Crain, P. K. \& Quiñones, R. M. 2013. Climate Change Vulnerability of Native and Alien Freshwater Fishes of California: A Systematic Assessment Approach. PLoS ONE 8, e63883

Natural England 2014. Climate Change Adaptation Manual - Evidence to support nature conservation in a changing climate (NE546). Natural England, York. (http://publications.naturalengland.org.uk/publication/5629923804839936)

Natural England 2015. Natural England's climate change risk assessment and adaptation plan (2015) (NE612). Natural England, York. http://publications.naturalengland.org.uk/publication/4599517514039296 
Newson, S.E., Oliver, T.H., Gillings, S., Crick, H.Q.P., Morecroft, M.D., Duffield, S.J., Macgregor, N.A. \& Pearce-Higgins, J.W. 2014. Can site and landscape-scale environmental attributes buffer bird populations against weather events? Ecography 37, 872-882

Ockendon, N., Baker, D.J., Carr, J.A., Almond, R.E.A., Amano, T., Bertram, E., Bradbury, R.B., Bradley, C., Butchart, S.H.M., Doswald, N., Foden, W., Gill, D.J.C., Green, R.E., Sutherland, W.J., Tanner, E.V.J. \& Pearce-Higgins, J.W. 2014. Mechanisms underpinning climatic impacts on natural populations: altered species interactions are more important than direct effects. Glob. Ch. Biol. 20, 2221-2229

Oliver, T. H., Smithers, R. J., Bailey, S., Walmsley, C. A. \& Watts, K. 2012. A decision framework for considering climate change adaptation in biodiversity conservation. J. Appl. Ecol. 49, 1247-1255.

Oliver, T.H., Marshall, H.H., Morecroft, M.D., Brereton, T., Prudhomme, C. \& Huntingford, C. 2015. Interacting effects if climate change and habitat fragmentation on drought-sensitive butterflies. Nat. Clim. Ch. 5, 941-945

Oliver, T.H., Gillings, S., Pearce-Higgins, J.W., Brereton, T., Crick, H.Q.P., Duffield, S.J., Morecroft, M.D. \& Roy, D.B. 2017. Large extents of intensive land use limit community reorganisation during climate warming. Glob. Ch. Biol. doi: 10.1111/gcb.13587

Pearce-Higgins, J.W. 2010. Using diet to assess the sensitivity of northern and upland birds to climate change. Clim. Res. 45, 119-130.

Pearce-Higgins, J.W. \& Green, R.E. 2014. Birds and Climate Change: Impacts and Conservation Responses. Cambridge University Press, Cambridge. 
Prentice, C., Cramer, W., Harrison, S.P., Leemans, R., Monserud, R.A. \& Solomon, A.M. 1992. A global biome model based on plant physiology and dominance, soil properties and climate. J. Biogeog. 19, 117-134.

Preston, C. D., Pearman, D. A. \& Dines, T. D. 2002. New Atlas of the British and Irish Flora. Oxford University Press, Oxford, UK.

Roth, T., Kohli, L., Rihm, B. \& Achermann, B. 2013. Nitrogen deposition is negatively related to species richness and species composition of vascular plants and bryophytes in Swiss mountain grassland. Agric. Ecosys. \& Env. 178, 121-126.

Roy, H. E., Adriaens, T., Isaac, N. J. B., Kenis, M., Martin, G. S., Brown, P. M. J., Hautier, L., et al., 2012. Invasive alien predator causes rapid declines of native European ladybirds. Divers \& Distrib. 18, 717-725.

Sexton, D.M.H., Harris, G. \& Murphy, J. 2010. UKCP09: Spatially Coherent Projections. Met Office (http://ukclimateprojections.metoffice.gov.uk/media.jsp?mediaid=88001\&filetype=pdf).

Stephens, P.A., Mason, L.R., Green, R.E., Gregory, R.D., Sauer, J.R., Alison, J., Aunins, A., Brotons, L., Butchart, S.H.M., Campedelli, T., Chodkiewicz, T., Chylarecki, P., Crowe, O., Elts, J., Escandell, V., Foppen, R.P.B., Heldbjerg, H., Herrando, S., Husby, M., Jiguet, F., Lehikoinen, A., Lindström, Å., Noble, D.G., Paquet, J., Reif, J., Sattler, T., Szép, T., Teufelbauer, N., Trautmann, S., van Strien, A.J., van Turnhout, C.A.M., Vorisek, P. \& Willis, S.G. 2016. Consistent response of bird populations to climate change on two continents. Science 352, 84-87.

Suggitt, A.J., Wilson, R.J., August, T.A., Beale, C.M., Bennie, J.J., Dordolo, A., Fox, R., Hopkins, J.J., Isaac, N.J.B., Jorieux, P., Macgregor, N.A., Marcetteau, J., Massimino, D., 
Morecroft, M.D., Pearce-Higgins, J.W., Walker, K., Maclean, I.M.D. 2014. Climate change refugia for the flora and fauna of England. Sheffield, Natural England, 210pp.

Sutton, P.G. 2015. A review of the scarce and threatened Orthoptera and allied species of Great Britain, Orthoptera, Dictyoptera, Dermaptera, Phasmida. Species Status No. 21, Natural England Commissioned Reports, 1-51, http://publications.naturalengland.org.uk/publication/5368778738106368

Thomas, C.D., Cameron, A., Green, R.E., Bakkenes, M., Beaumont, L.J., Collingham, Y.C., Erasmus, B.F.N., de Siquieira, M.F., Grainger, A., Hannah, L., Hughes, L., Huntley, B., van Jaarsveld, A.S., Midgley, G.F., Miles, L., Ortega-Huerta, M.A., Peterson, A.T., Phillips, O.L., Williams, S.E. 2004. Extinction risk from climate change. Nature 427, 145-148.

Thomas, C.D., Gillingham, P.K., Bradbury, R.B., Roy, D.B., Anderson, B.J., Baxter, J.M., Bourn, N.A.D., Crick, H.Q.P., Findon, R.A., Fox, R., Hodgson, J.A., Holt, A.R., Morecroft, M.D., O’Hanlon, N., Oliver, T.H., Pearce-Higgins, J.W., Procter, D.A., Thomas, J.A., Walker, K.J., Walmsley, C.A., Wilson, R.J. \& Hill, J.K. 2012. Protected areas facilitate species’ range expansions. Proc. Nat. Acad. Sci. USA 109, 14063-14068.

Thomas, C.D., Hill, J.K., Anderson, B.J., Bailey, S., Beale, C.M., Bradbury, R.B., Bulman, C.R., Crick, H.Q.P., Eigenbrod, F., Griffiths, H.M. ,Kunin, W.E., Oliver, T.H., Walsmley, C.A., Watts, K., Worsfold, N.T. \& Yardley, T. 2010. A framework for assessing threats and benefits to species responding to climate change. Meth. Ecol. \& Evol. 2, 125-142.

Walmsley, C.A., Smithers, R.J., Berry, P.M., Harley, M., Stevenson, M.J. \& Catchpole, R. 2007. MONARCH - Modelling Natural Resource Responses to Climate Change - a synthesis for biodiversity conservation. UKCIP, Oxford. 
Warren, M.S., Hill, J.K., Thomas, J.A., Asher, J., Fox, R., Huntley, B., Roy, D.B., Telfer, M.G., Jeffcoate, S., Harding, P., Jeffcoate, G., Willis, S.G., Greatorex-Davies, J.N., Moss, D. \& Thomas, C.D.2001. Rapid responses of British butterflies to opposing forces of climate and habitat change. Nature. 414:65-69.

Warren, R., VanDerWal, J., Price, J., Welbergen, J.A., Atkinson, I., Ramirez-Villegas, J., Osborn, T.J., Jarvis, A., Shoo, L.P., Williams, S.E. \& Lowe, J. 2013. Quantifying the benefit of early climate change mitigation in avoiding biodiversity loss. Nat. Clim. Ch. 3:678-682. 
Table 1. Summary of the coverage of different species groups by this risk assessment.

\begin{tabular}{|c|c|c|c|c|c|c|}
\hline Taxon & Recording Scheme & Link & $\begin{array}{c}\text { Total species } \\
\text { with distribution } \\
\text { data }\end{array}$ & $\begin{array}{l}\text { Species for which } \\
\text { climate models } \\
\text { converged }\end{array}$ & $\begin{array}{l}\text { Species for which } \\
\text { trends could be } \\
\text { calculated }\end{array}$ & \begin{tabular}{|c} 
Conservation \\
priority species \\
with trends \\
calculated
\end{tabular} \\
\hline Ants & $\begin{array}{c}\text { Bees, Wasps and Ants } \\
\text { Recording } \\
\text { Society (BWARS) }\end{array}$ & www.bwars.com & 36 & 28 & 13 & 0 \\
\hline Bees & $\begin{array}{c}\text { Bees, Wasps and Ants } \\
\text { Recording } \\
\text { Society (BWARS) }\end{array}$ & www.bwars.com & 225 & 187 & 143 & 6 \\
\hline Birds & $\begin{array}{c}\text { British Trust for } \\
\text { Ornithology }\end{array}$ & Www.bto.org & 180 & $180^{1}$ & 180 & 41 \\
\hline
\end{tabular}




\begin{tabular}{|c|c|c|c|c|c|c|}
\hline Bryophytes & $\begin{array}{c}\text { British Bryological } \\
\text { Society }\end{array}$ & $\begin{array}{c}\frac{\text { www.britishbryologicalsociet }}{\text { y.org.uk }} \\
\end{array}$ & 1,049 & 850 & 520 & 1 \\
\hline Carabid beetles & $\begin{array}{c}\text { Ground Beetle } \\
\text { Recording Scheme }\end{array}$ & $\begin{array}{c}\text { http://www.brc.ac.uk/scheme/ } \\
\text { ground-beetle-recording- } \\
\text { scheme }\end{array}$ & 317 & 266 & 175 & 3 \\
\hline $\begin{array}{l}\text { Centipedes \& } \\
\text { millipedes }\end{array}$ & $\begin{array}{l}\text { British Myriapod and } \\
\text { Isopod Group, } \\
\text { Centipede and } \\
\text { Millipede Recording } \\
\text { Schemes }\end{array}$ & www.bmig.org.uk & 85 & 66 & 39 & 0 \\
\hline Cerambycid Beetles & $\begin{array}{c}\text { Cerambycidae } \\
\text { Recording Scheme }\end{array}$ & $\begin{array}{c}\text { http://www.coleoptera.org.uk/ } \\
\text { cerambycidae/home }\end{array}$ & 52 & 40 & 0 & 0 \\
\hline Coccinelid beetles & $\begin{array}{c}\text { Ladybird } \\
\text { Recording Scheme }\end{array}$ & www.ladybird-survey.org & 44 & 38 & 17 & 0 \\
\hline
\end{tabular}




\begin{tabular}{|c|c|c|c|c|c|c|}
\hline Craneflies & $\begin{array}{l}\text { Dipterists Forum, } \\
\text { Cranefly Recording } \\
\text { Scheme }\end{array}$ & www.dipteristsforum.org.uk & 78 & 64 & 11 & 0 \\
\hline $\begin{array}{l}\text { Crickets \& } \\
\text { grasshoppers }\end{array}$ & $\begin{array}{c}\text { Orthoptera Recording } \\
\text { Scheme }\end{array}$ & www.orthoptera.org.uk & 43 & 31 & 23 & 0 \\
\hline $\begin{array}{l}\text { Dragonflies \& } \\
\text { damselflies }\end{array}$ & $\begin{array}{l}\text { British Dragonfly } \\
\text { Society, Dragonfly } \\
\text { Recording Network }\end{array}$ & $\begin{array}{c}\text { www.british- } \\
\text { dragonflies.org.uk }\end{array}$ & 45 & 35 & 26 & 0 \\
\hline Hoverflies & $\begin{array}{l}\text { Dipterists Forum, } \\
\text { Hoverfly Recording } \\
\text { Scheme }\end{array}$ & www.hoverfly.org.uk & 249 & 213 & 175 & 0 \\
\hline Moths & Butterfly Conservation & $\begin{array}{l}\frac{\text { www.mothscount.org/text/27/ }}{\text { national_moth_recording_sch }} \\
\underline{\text { eme.html }}\end{array}$ & 668 & 622 & 422 & 58 \\
\hline
\end{tabular}




\begin{tabular}{|c|c|c|c|c|c|c|}
\hline $\begin{array}{l}\text { Soldier Beetles and } \\
\text { allies }\end{array}$ & $\begin{array}{l}\text { Soldier Beetles, Jewel } \\
\text { Beetles and Glow- } \\
\text { worms Recording } \\
\text { Scheme }\end{array}$ & $\begin{array}{l}\text { http://www.brc.ac.uk/scheme/ } \\
\text { soldier-beetles-jewel-beetles- } \\
\text { and-glow-worms-recording- } \\
\text { scheme }\end{array}$ & 53 & 46 & 22 & 0 \\
\hline Spiders & $\begin{array}{l}\text { Spider Recording } \\
\text { Scheme, British } \\
\text { Arachnological } \\
\text { Society }\end{array}$ & $\begin{array}{l}\text { www.srs.britishspiders.org.uk, } \\
\underline{\text { www.BritishSpiders.org.uk }}\end{array}$ & 512 & 374 & 297 & 7 \\
\hline Vascular plants & $\begin{array}{l}\text { Botanical Society of } \\
\text { Britiain and Ireland } \\
\text { (BSBI) }\end{array}$ & www.bsbi.org.uk & 1,365 & $1,339^{2}$ & 852 & 38 \\
\hline Wasps & \begin{tabular}{|} 
Bees, Wasps and Ants \\
Recording \\
Society (BWARS)
\end{tabular} & www.bwars.com & 219 & 161 & 133 & 1 \\
\hline
\end{tabular}




\section{TOTAL}

${ }^{1}$ Models for two species failed to converge when built using only GB data.

${ }^{2}$ For 354 of these, European data were also available. 
Table 2. Cross-tabulation of the risks and opportunities associated with climate change for all 3048 species run through the simplified risk assessment, based upon a low emission B1 projection for 2070-2099 (see Tables A3 and A4 for the derivation and interpretation of each category). Values are the numbers of species in each category.

\section{RISK}

\section{VERY HIGH HIGH MEDIUM LOW TOTALS}

\begin{tabular}{lllllll}
\hline & LOW & 25 & 1 & 7 & 6 & 39 \\
\cline { 2 - 7 } & MEDIUM & 614 & 157 & 481 & 84 & 1,336 \\
\cline { 2 - 7 } & HIGH & 24 & 27 & 358 & 142 & 551 \\
\cline { 2 - 7 } & VERY HIGH & 56 & 44 & 662 & 360 & 1,122 \\
\hline \multirow{2}{*}{} & & & & & & \\
\hline
\end{tabular}


Table 3. Cross-tabulation of the risks and opportunities associated with climate change for 402 species from all taxonomic groups run through the full risk assessment, based upon a low emission B1 projection for 2070-2099. Values in parentheses are the values for the species of conservation concern only.

\section{RISK}

\section{VERY HIGH HIGH MEDIUM LOW TOTALS}

\begin{tabular}{|c|c|c|c|c|c|c|}
\hline \multirow{4}{*}{ 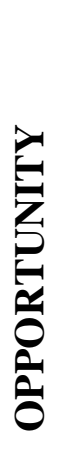 } & LOW & $67(34)$ & $37(11)$ & $21(7)$ & $75(27)$ & $200(79)$ \\
\hline & MEDIUM & $5(3)$ & $2(0)$ & $1(0)$ & $22(11)$ & $30(14)$ \\
\hline & HIGH & $9(4)$ & $9(4)$ & $7(3)$ & $64(26)$ & $89(37)$ \\
\hline & VERY HIGH & $8(5)$ & $4(2)$ & $5(1)$ & $66(17)$ & $83(25)$ \\
\hline & TOTALS & $89(46)$ & $51(17)$ & $34(11)$ & $227(81)$ & $402(155)$ \\
\hline
\end{tabular}




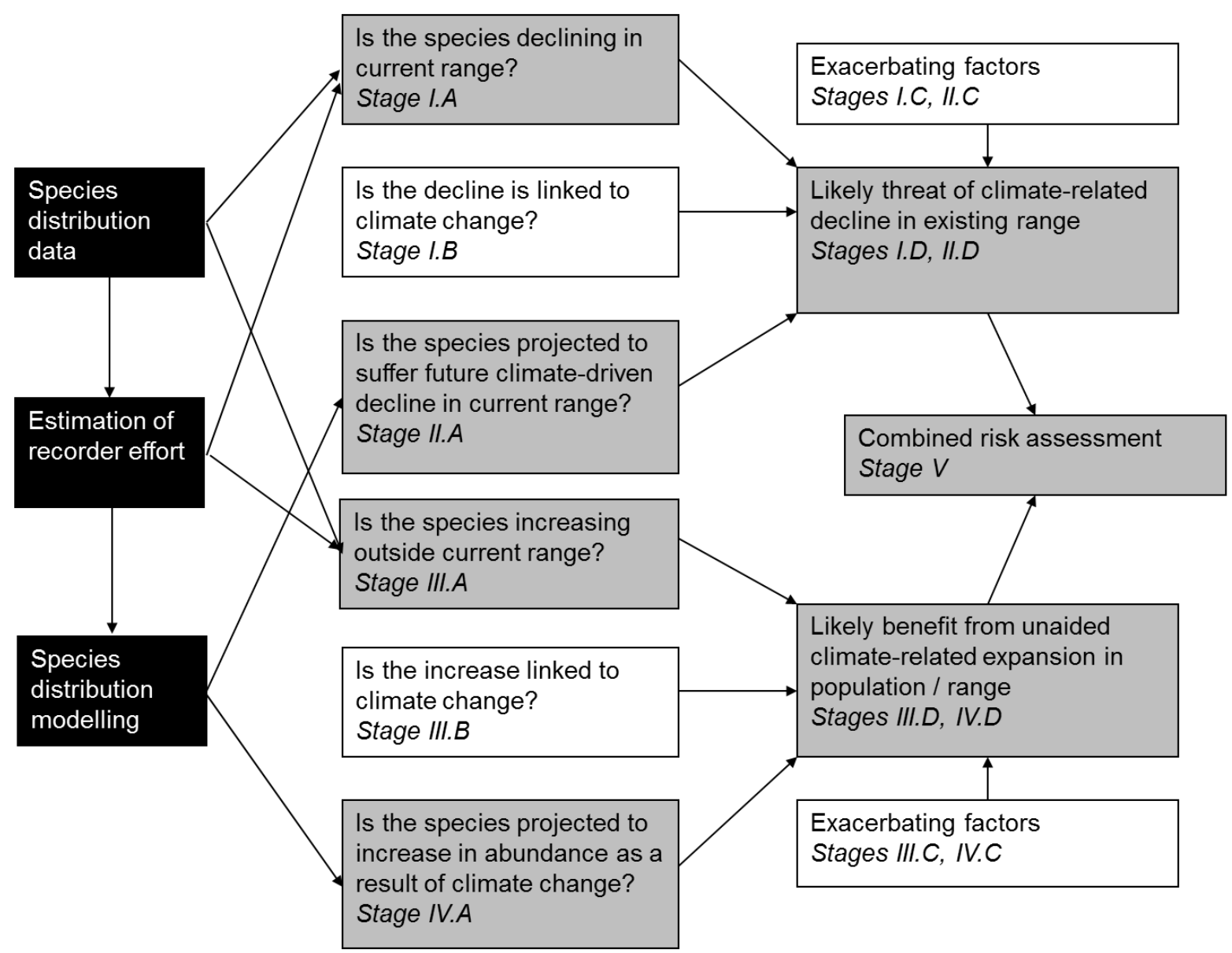

Figure 1. Summary of the processes involved in the application of the full risk assessment

(simplified from Thomas et al., 2011), and how those are represented by the various stages of the process. Black boxes indicate the information required prior to risk assessment.Boxes in grey represent the steps of the simplified risk assessment. 

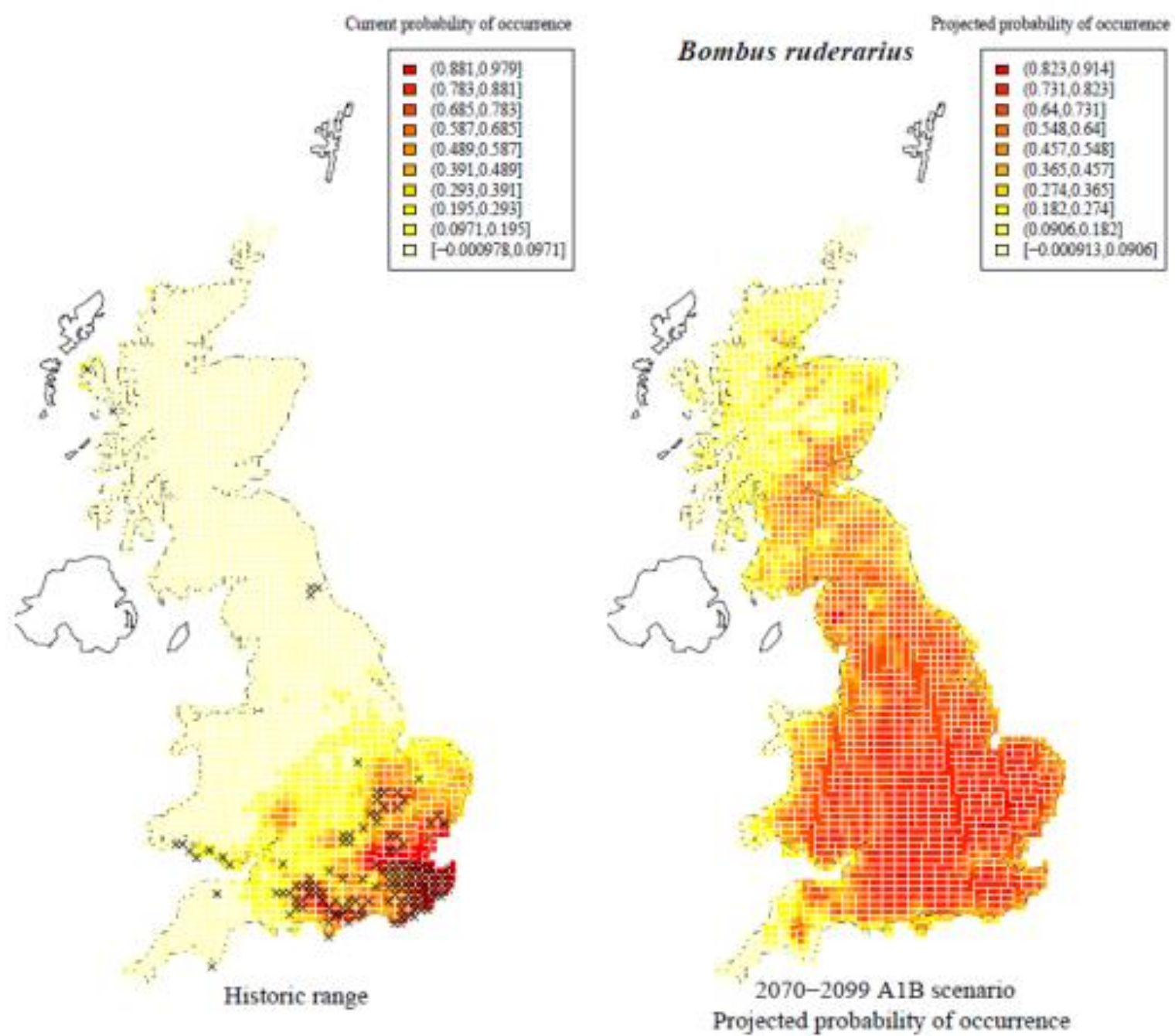

Figure 2. The historic (1970-1990) probability of occurrence of an example species, Bombus ruderarius, (left) and the projected probability of occurrence under a medium emissions A1B scenario (right). Black crosses show actual records and coloured squares show modelled probability of occurrence. 


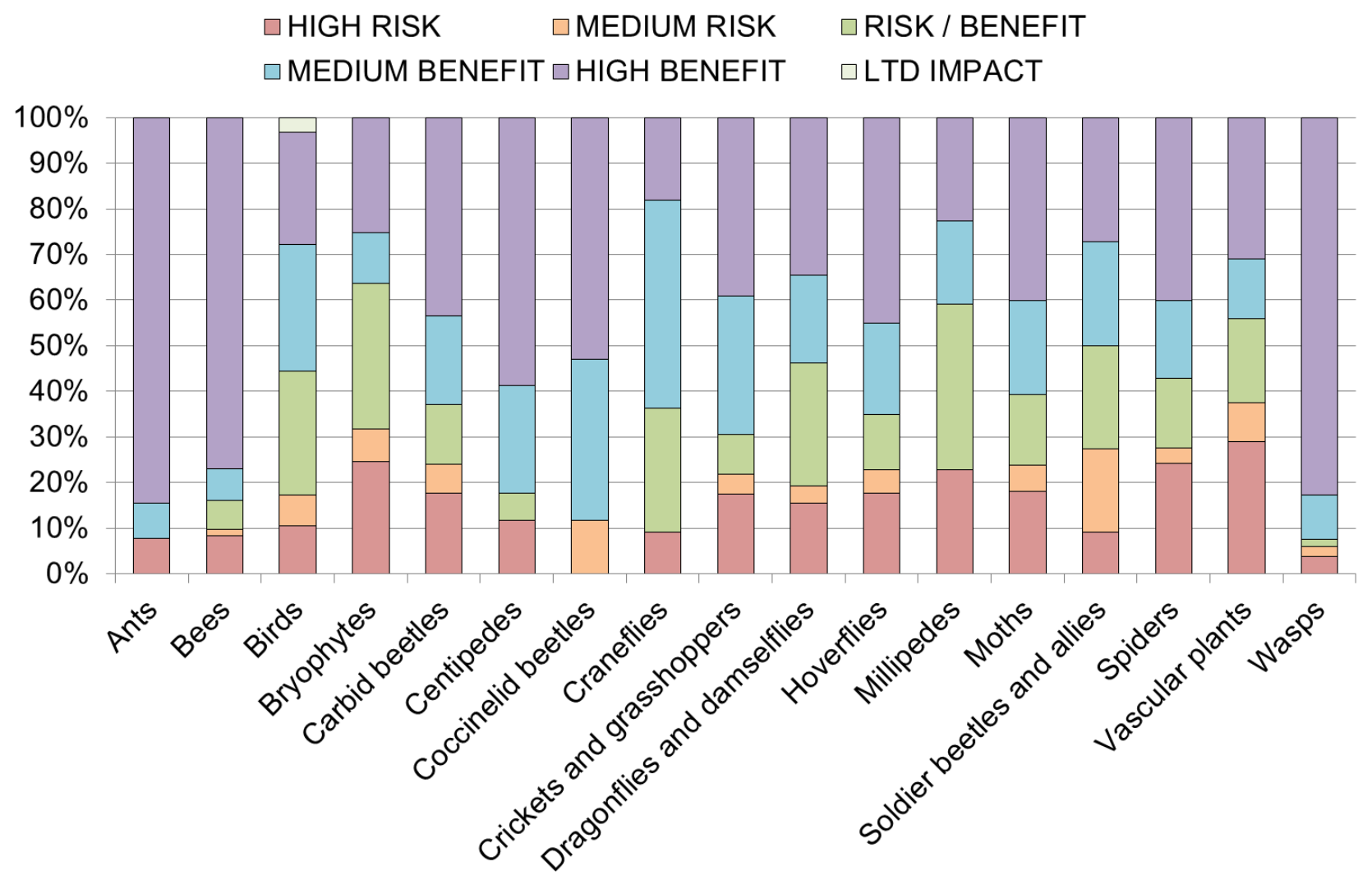

Figure 3. Proportion of species categorised as likely to be at risk or to benefit from climate change, based upon a low emission B1 projection for 2070-2099, in different taxonomic groups, as assessed by the simplified risk assessment. The sample size of species for each group is given in Table 1. 


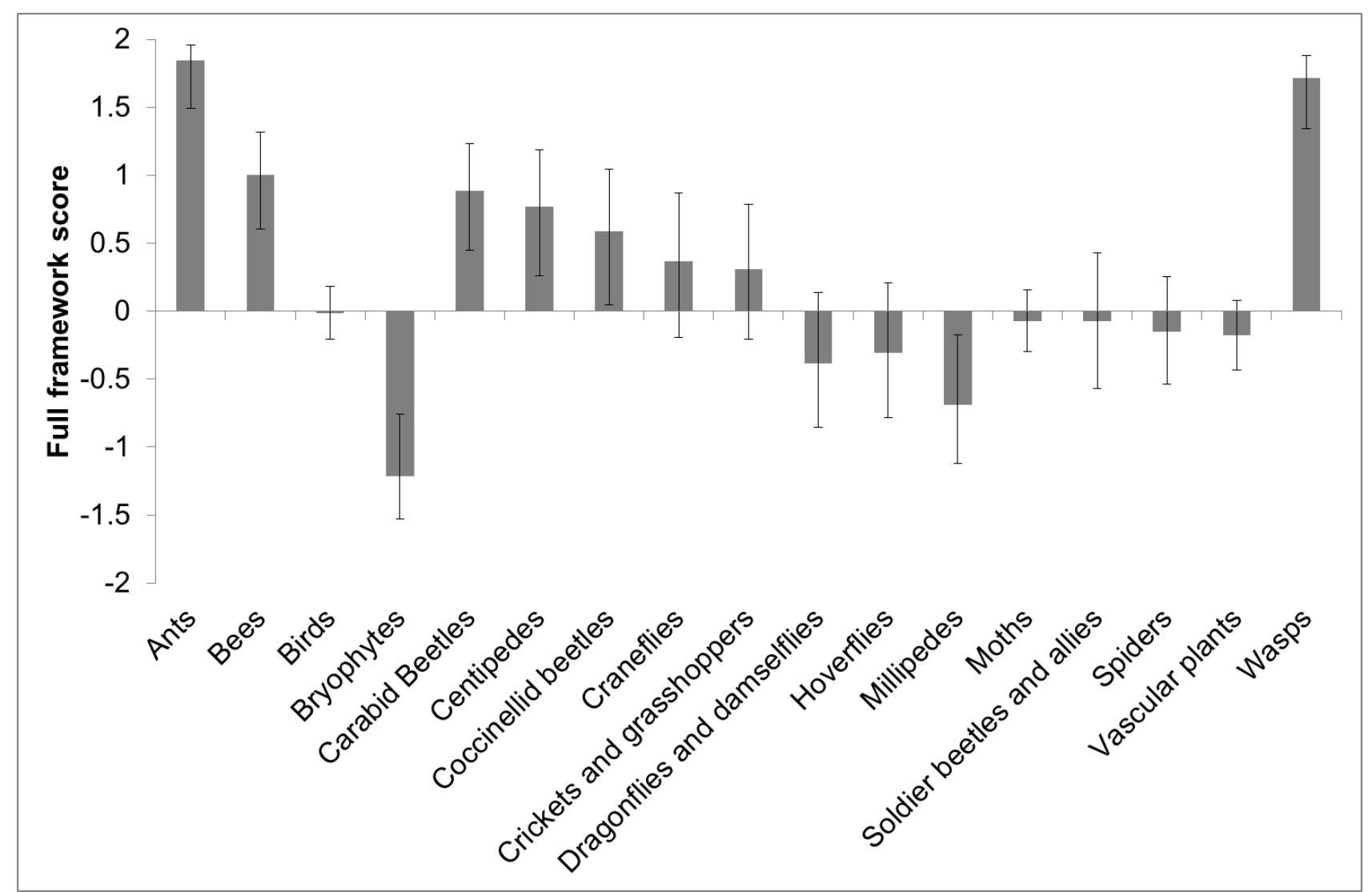

Figure 4. Modelled full risk assessment score for each taxonomic group, from a GLM

containing taxonomic group and conservation status. Presented are least-square means from the model with standard errors. A score of 2 is equivalent to high opportunity, 1, medium opportunity, 0 risk and opportunity or no impact, -1 medium risk and -2 high risk. 


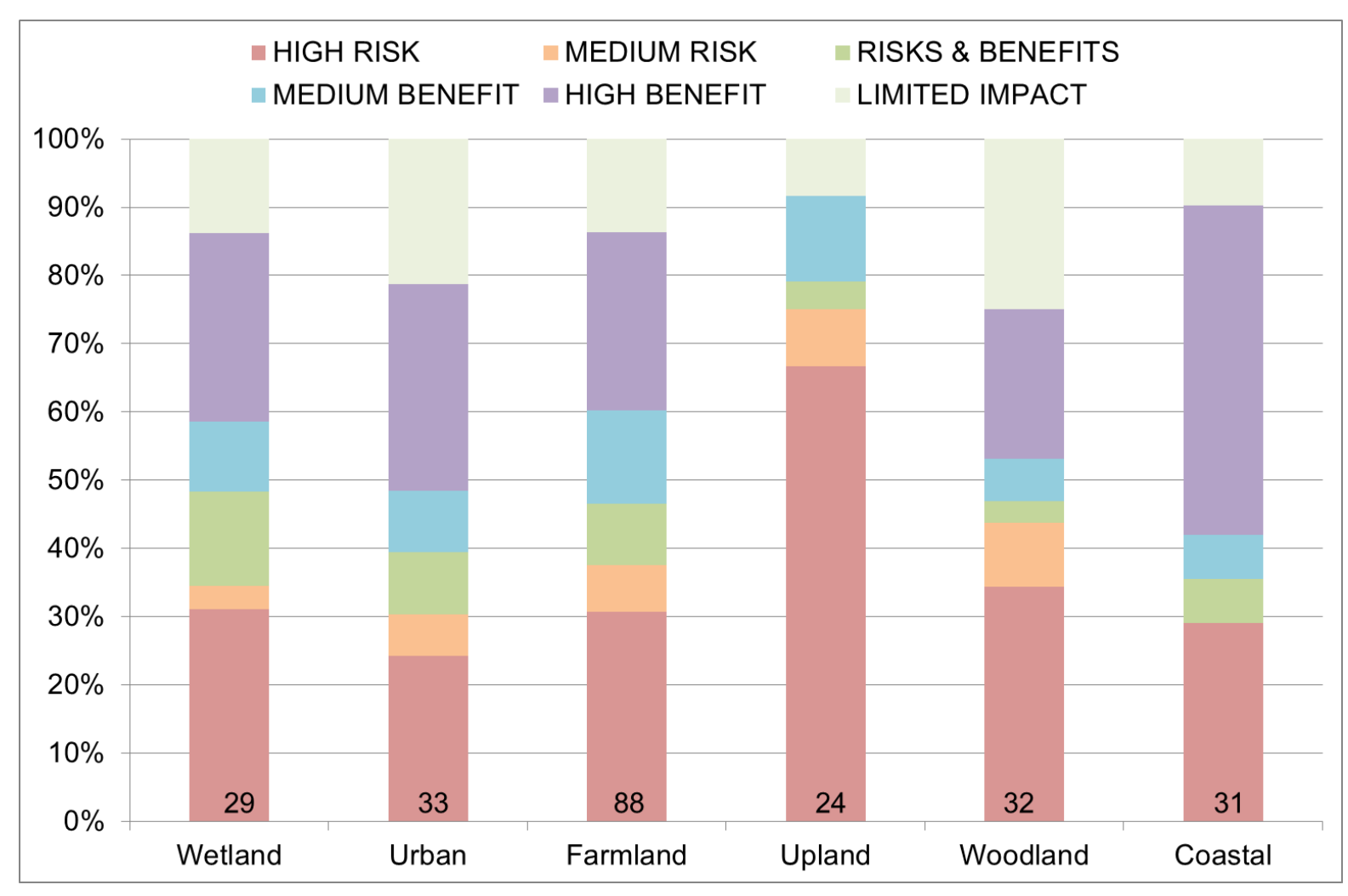

Figure 5. Proportion of species categorised as likely to be at risk from climate change, or to face opportunity, using the full risk assessment, according to the habitat each species is associated with. The sample size for each habitat is shown by the number on each column. About half of species contributed information to more than one habitat. Habitat association information was available for the NERC species of conservation concern only. The results are based upon a low emission B1 projection for 2070-2099 


\section{Appendix 1. Bioclimate modelling}

To improve the ability of the models to describe associations with climates that are rare or novel for Britain, following Beale et al. (2014), we incorporated data from Europe. European distribution data were acquired from the European Bird Census Council (Hagemeijer \& Blair 1997) and the Atlas Florae Europaeae (http://www.luomus.fi/en/atlas-florae-europaeae-afedistribution-vascular-plants-europe) for birds and plants respectively. Iceland and the Faroe Islands were excluded due to their isolation from the rest of Europe, which aided model convergence. Cells east of longitude $29.99^{\circ}$ were also excluded to avoid problems of low observer effort. This yielded 2,644 $50 \mathrm{~km}$ cells across Europe and we identified species' presence within these from the native portions of each species range (excluding locations were European native species have been introduced).

Observed climate data on a $5 \mathrm{~km}$ grid from the period 1961-90 were downloaded for Britain from the UK Meteorological Office web site (http://www.metoffice.gov.uk/climatechange/science/monitoring/ukcp09/). These were taken to represent the baseline climate that would be used to describe observed baseline species distributions, and were aggregated to a $10 \mathrm{~km}$ grid for analysis. Future projection data were downloaded from the UKCP09 user interface (http://ukclimateprojections-ui.defra.gov.uk). To ensure that climate data were consistent across adjacent grid cells and that different climate variables were consistent within the same grid cell, we used the Spatially Coherent Projections (Sexton et al., 2010), rescaled to a $10 \mathrm{~km}$ resolution to model change. To represent GB climate under global temperature increases of $2^{\circ} \mathrm{C}$ and $4{ }^{\circ} \mathrm{C}$ since pre-industrial times, we used 2070-99 for scenarios B1 and A1B respectively (http://ukclimateprojections.defra.gov.uk/22614), as equivalent outputs from the more recent RCP scenarios were not available at the time of this work. Projections were based on data 
from 11 Regional Climate Model (RCM) ensemble members. For European-scale models, observed climate data from the period 1961-90 were acquired from the Tyndall Centre for Climate Change Research; dataset CRU TS 1.2 (Mitchell 2004). These data were averaged across the required $50 \mathrm{~km}$ UTM grid for Europe, and used to calculate the four bioclimatic variables outlined above.

To test the effect of incorporating European data upon projections for GB, we repeated the models for birds and vascular plants under the A1B scenario using only data for GB. The predicted changes in extent from this model were strongly correlated with predicted changes from models using the European data to generate informative priors $(\mathrm{r}=0.691, \mathrm{n}=532, P<$ 0.0001). There was no significant difference in the relationship between the two measures of projected change between birds and vascular plants $\left(\mathrm{F}_{1,528}=0.052, P=0.82\right)$. However, models based on data from GB only tended to result in fewer species showing a potential increase in range (58\% forecast to increase using European data compared to $46 \%$ from GB only data) which should be remembered when interpreting the results. 
Table A1. Cross-tabulation of the threats and opportunities associated with climate change for 2070-2099 for all species based upon the simplified risk assessment (see Tables A3 and A4 for the derivation of each category). Values are the numbers of species in each category.

\section{THREAT}

\section{VERY HIGH HIGH MEDIUM LOW TOTALS}

\begin{tabular}{|c|c|c|c|c|c|c|}
\hline \multirow{4}{*}{ 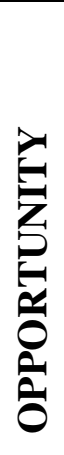 } & LOW & 25 & 1 & 7 & 6 & 39 \\
\hline & MEDIUM & 657 & 135 & 475 & 75 & 1,342 \\
\hline & HIGH & 31 & 23 & 343 & 135 & 532 \\
\hline & VERY HIGH & 44 & 48 & 677 & 366 & 1,135 \\
\hline & TOTALS & 757 & 207 & 1502 & 582 & 3,048 \\
\hline
\end{tabular}


Table A2. Cross-tabulation of the threats and opportunities associated with climate change for 2070-2099 for all species based upon the full risk assessment. Values in parentheses are the values for the NERC species of conservation concern only.

\section{THREAT}

TOTAL

VERY HIGH HIGH MEDIUM LOW S

\begin{tabular}{|c|c|c|c|c|c|c|}
\hline \multirow{4}{*}{ 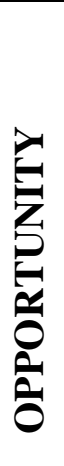 } & LOW & $79(37)$ & $37(11)$ & $18(6)$ & $73(27)$ & $208(81)$ \\
\hline & MEDIUM & $2(2)$ & $2(0)$ & $4(1)$ & $21(8)$ & $28(11)$ \\
\hline & HIGH & $8(5)$ & $7(3)$ & $5(4)$ & $66(27)$ & $86(39)$ \\
\hline & VERY HIGH & $6(4)$ & $3(2)$ & $5(2)$ & $66(16)$ & $80(24)$ \\
\hline & TOTALS & $95(48)$ & $50(16)$ & $32(13)$ & $226(78)$ & 402 (155) \\
\hline
\end{tabular}




\section{Appendix 2. Correcting for variation in observer effort.}

Mixed-effects models of the probability of occurrence within 'well-sampled' $1 \mathrm{~km}$ squares as a function of time, were used to measure trends in area of occupancy within the baseline historical range, whilst minimising the risk of bias from changing observer effort (Roy et al., 2012). Well-sampled squares were defined as those visited on at least three occasions when at least four species of a particular taxonomic group were recorded. Occurrence was modelled within a generalised linear mixed model with site as a random effect and year as a fixed effect using the function WSS (https://zenodo.org/record/208752\#.WFfNiFOLRQI). The resulting coefficient of the year term was converted into a percentage decadal change in the estimated probability of occupancy. For poorly-surveyed species, the well-sampled squares we analysed are likely to be a small subset of the true historic range of the species, and so our method assumes that the frequency of species loss from these well surveyed squares accurately represents losses across the true historic range.

More recent data from 1990-2009 were analysed at the hectad resolution to document range change and assess colonisation outside of the historical range. Such analyses controlled for recorder effort, indexed as the proportion of species observed in a hectad relative to the total number of species expected, using the program FRESCALO (Hill 2012) implemented in 'sparta' (citation here: https://zenodo.org/record/208752\#.WFfNiFOLRQI). We selected a threshold of recorder effort of 0.25 ( $25 \%$ of likely species being recorded) to define an 'adequately sampled' square. The number of colonised hectads was calculated as the number of hectads occupied in the second time period but not in the first time period, considering only hectads that were 'adequately sampled' in both time periods. This was then divided by the number of 'adequately sampled' hectads within the home range which were occupied in 
the first time period. This overall change was then converted to a decadal percentage change value. 
Appendix 3. Cross-tabulation of risks and opportunities for the simplified risk assessment

Observed contractions within the historical range were compared against the magnitude of projected future contractions to assess risk from climate change, whilst observed range expansion was cross-tabulated with the magnitude of projected future range expansion to assess potential threats and opportunities from climate change (Table A3). These outputs were cross-tabulated to provide an overall assessment of risks and opportunities for each species (Figure 1; Table A4). 
Table A3. Cross-tabulation of likely threat to species (top) and opportunity for species (bottom) from climate change based on observed (rows) and projected (columns) decadal changes in range extent within the current range.

\section{PROJECTED DECREASE}

$$
>7.5 \% \quad 4.0-7.5 \% \quad 1.0-4.0 \% \quad<1.0 \%
$$

\begin{tabular}{|c|c|c|c|c|c|}
\hline \multirow{4}{*}{ 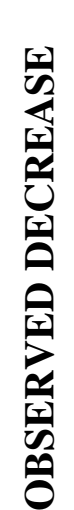 } & $>7.5 \%$ & VERY HIGH & VERY HIGH & HIGH & MEDIUM \\
\hline & $4.0-7.5 \%$ & VERY HIGH & HIGH & HIGH & MEDIUM \\
\hline & $1.0-4.0 \%$ & HIGH & HIGH & MEDIUM & MEDIUM \\
\hline & $<1.0 \%$ & MEDIUM & MEDIUM & MEDIUM & LOW \\
\hline
\end{tabular}

PROJECTED INCREASE

$\begin{array}{llll}>7.5 \% & 4.0-7.5 \% & 1.0-4.0 \% & <1.0 \%\end{array}$

\begin{tabular}{|c|c|c|c|c|c|}
\hline \multirow{4}{*}{ 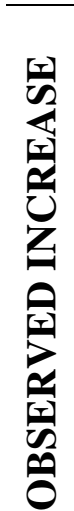 } & $>7.5 \%$ & VERY HIGH & VERY HIGH & HIGH & MEDIUM \\
\hline & $4.0-7.5 \%$ & VERY HIGH & HIGH & HIGH & MEDIUM \\
\hline & $1.0-4.0 \%$ & HIGH & HIGH & MEDIUM & MEDIUM \\
\hline & $<1.0 \%$ & MEDIUM & MEDIUM & MEDIUM & LOW \\
\hline
\end{tabular}


Table A4. Cross-tabulation of the risk and opportunities (Table A3) associated with climate change for each species, in order to summarise the risks (columns) and opportunities (rows) for each species.

\section{RISK}

VERY HIGH HIGH MEDIUM LOW

\begin{tabular}{|c|c|c|c|c|c|}
\hline \multirow{4}{*}{ 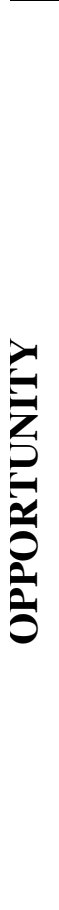 } & LOW & HIGH RISK & HIGH RISK & MEDIUM RISK & $\begin{array}{l}\text { LIMITED } \\
\text { IMPACT }\end{array}$ \\
\hline & MEDIUM & HIGH RISK & MEDIUM RISK & $\begin{array}{c}\text { RISKS \& } \\
\text { OPPORTUNITY }\end{array}$ & $\begin{array}{c}\text { MEDIUM } \\
\text { OPPORTUNITY }\end{array}$ \\
\hline & HIGH & MEDIUM RISK & $\begin{array}{c}\text { RISKS \& } \\
\text { OPPORTUNITY }\end{array}$ & $\begin{array}{c}\text { MEDIUM } \\
\text { OPPORTUNITY }\end{array}$ & $\begin{array}{c}\text { HIGH } \\
\text { OPPORTUNITY }\end{array}$ \\
\hline & VERY HIGH & $\begin{array}{c}\text { RISKS \& } \\
\text { OPPORTUNITY }\end{array}$ & $\begin{array}{c}\text { MEDIUM } \\
\text { OPPORTUNITY }\end{array}$ & $\begin{array}{c}\text { HIGH } \\
\text { OPPORTUNITY }\end{array}$ & $\begin{array}{c}\text { HIGH } \\
\text { OPPORTUNITY }\end{array}$ \\
\hline
\end{tabular}




\section{Appendix 4. Detail of the methods and information required for full risk assessment}

See Figure 1 for an overview of the risk assessment process.

\section{Stage I.}

Distribution change data (Stage I.A) were based on Atlas data (for birds) and modelling of recording scheme data held by Biological Records Centre (BRC) as described above for other taxa. Confidence in all bird trends was assessed as good, based on the high coverage and effort. For other taxa, confidence was assessed as good if the mixed model accounting for recorder effort gave a trend where the upper $80 \%$ confidence intervals were in the same impact category as the trend (i.e. we were $80 \%$ confident that any observed declines were at least that severe), unless experts highlighted that significant changes in recorder effort, taxonomy or identifiability may have contributed to these trends. The linkage between range decline and climate (Stage I.B) was assessed initially by comparison of the direction of observed and projected declines within the current range. If both were negative then this provided evidence for a link (with poor confidence), if they were contradictory in direction then this provided no evidence for a link and if evidence existed in the published literature for a relationship between climate and population or range change, this was regarded as providing evidence of a link with good confidence. In Stage I.C exacerbating factors and associated confidence were assessed from expert opinion and the scientific literature, with a published study supporting the importance of a particular impact on a species' population or distribution regarded as providing evidence with good confidence.

Stage II.

Projected declines within the current range were estimated using outputs from species distribution modelling. Confidence in these projections was assigned as 'high' where 
projected and recently observed trends were consistent and the confidence intervals of bioclimatic models (median confidence interval across squares divided by the variance) were less than a threshold value of 0.02 (selected from a visual assessment of the spread of values). Confidence was assigned as medium if the confidence interval threshold was met but projected and observed trends were in opposing directions, indicating that non-climatic factors had driven recent trends. Confidence was low if the median weighted confidence interval was $>0.02$, suggesting that the model projections were uncertain.

Stage III.

Stage III.A and III.B were completed as for Stages I.A and 1.B, but using information about range expansion rather than contraction. The only difference was that, as described in Thomas et al., (2010), decadal population increases in section III.A were calculated relative to the species' status updated every decade, (as opposed to Stage I.A where changes were calculated relative to the species original status).

\section{Stage IV.}

Stage IV.A was based on bioclimatic projections of range expansion outside the current range, calculated as (newly colonised range) / ( newly colonised range +current range). Confidence was assigned as in Stage II.A. Assessments of exacerbating factors likely to limit range expansion, and our confidence in them (Stage IV.C) were again based on expert knowledge and the literature. 
Table A5. Summary of the information required at each stage of the full risk assessment (summarised and adapted from Thomas et al., 2010)

Stage Data sources and criteria used
I.A.impact
For bird species the decadal decline within current range was calculated from Atlas data between 1990-2010.
For all other taxa, a mixed effects model on BRC data controlling for recorder effort was used.

I.A.confidence

All bird species trends were assigned good confidence.

For other taxa, confidence was based on the C. I. from mixed model: if upper $80 \%$

C.I. overlaps the next impact category then confidence is poor, otherwise good.

I.B.impact

If both observed trend (I.A.) and projected trend (II.A.) are negative then linkage="Yes". Supplemented with literature review to assess additional linkages with climate

I.B.confidence $\quad$ Poor if just assessed by comparison of observed (I.A.) and projected (II.A.) trends.

Good if robust evidence identified by literature review.
I.C.i.impact
Is current extent $<20000 \mathrm{~km}^{2} ? *$

Additionally for bird species only: is GB population $<10000$ individuals?

I.C.i.confidence For bird species generally good.

For other taxa: poor if just assessed by using current extent data. Good if robust 
evidence identified by literature review or supported by expert opinion.

IC.ii.impact Expert knowledge or evidence from literature review supporting at least one of the factors.

I.Cii.confidence Good if robust evidence from peer-reviewed literature. Poor if based on expert knowledge alone.

For birds, due to generally good understanding of the ecology of these species, experts were asked to assign the confidence level where impact was based on unpublished information.

II.A.impact $\quad$ Bioclimate model projected change in occupancy within current range

II.A.confidence $\quad$ a) Are bioclimate confidence intervals below a threshold value (see main text)?

b) Is direction of projected trends (II.A.) in same direction as observed trend (I.A.)?

For bird species: Yes to a)\&b) = good, yes to a) only =medium, no to a) =poor.

For other taxa: Yes to a)\&b) = good, yes to a) or b) only =medium, no to a) $\&$ b) $=$ poor.

II.B. Not applicable

II.C.i.impact As I.C.i

II.Ci.confidence $\quad$ As I.C.i

II.C.ii.impact As I.C.ii

II.Cii.confidence As I.C.ii 


\begin{abstract}
III.A.impact $\quad$ For bird species: decadal increase outside previous range was calculated from Atlas data between 1990-2010.

Other taxa: mixed model of BRC data of observed increases beyond species' recent historical range** controlling for recorder effort
\end{abstract}

III.A.confidence All bird species trends were assigned with good confidence.

For other taxa: the model output was compared across 3 different levels of recorder effort - if the level of recorder effort changes the impact category then confidence is poor, otherwise assigned as good.

III.B.impact

If both observed trend (III.A.) and projected trend (IV.A.) are positive then linkage="Yes". Supplemented with literature review to assess additional linkages with climate.

III.B.confidence Poor if just assessed by comparing observed (III.A.) and projected trends (IV.A.). Good if robust evidence identified in literature review.
III.C.
Not applicable

IV.A.impact Bioclimate model projected change in occupancy outside the current range IV.A.confidence As II.A.

IV.B. Not applicable

IV.C.i. impact As I.C.ii

IV.C.i. confidence As I.C.ii 
IV.C.ii. impact As I.C.ii

IV.C.ii.confidence As I.C.ii

IV.C.iii. impact As I.C.ii

IV.C.iii.confidence As I.C.ii

Note we occasionally changed confidence levels in Stage A (usually 1.A.) if experts highlighted concerns regarding distribution data, e.g. significant changes in recorder effort, recent taxonomic splits, issues regarding taxonomic identification etc.

*Current extent is calculated by bioclimate model: probability of a cell being occupied multiplied by the area of a cell $=$ current extent (possible area occupied)

**Number of newly occupied cells outside the current range as a percentage of cells inside current range. 
Appendix 5. Species outcomes from the simplified risk assessment 
Appendix 6. Species outcomes from the full risk assessment 